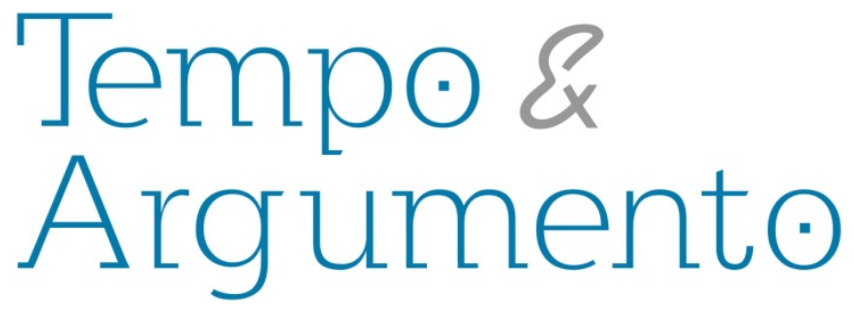

\title{
O direito à memória: a história oral de mulheres que lutaram contra a ditadura militar (1964 - 84)
}

\begin{abstract}
Resumo
Este artigo tem como proposta apresentar trabalhos historiográficos que trataram de testemunhos femininos sobre a luta contra a ditadura militar brasileira. Dentre eles, apresento também minha pesquisa de doutorado, desenvolvida a partir das histórias de vida de mulheres que resistiram contra a opressão, de forma silenciosa, tendo poucas vezes sido reconhecidas pela sociedade como sujeitos históricos. A história oral testemunhal exerce hoje um grande papel de denúncia e de direito à memória de grupos ainda pouco visíveis no cenário público, inclusive de mulheres, muitas vezes vistas como estranhas ao espaço político. Seus relatos revelam múltiplas formas de ações na luta contra o autoritarismo, mostrando que público e privado não são excludentes nem se opõem.
\end{abstract}

Palavras-chave: História oral testemunhal. Direito à memória. Mulheres. Ditadura militar.

\author{
Marta Gouveia de Oliveira Rovai \\ Doutora em História Social pela \\ Universidade de São Paulo, \\ professora da Universidade Estadual \\ do Piauí (UESPI), pesquisadora do \\ Núcleo de Estudos em História Oral \\ (NEHO/USP) e do Núcleo Cidade, \\ Cultura e Identidade (CCI/UESPI). \\ martarovai@usp.br
}

\section{Para citar este artigo:}

ROVAI, Marta Gouveia de Oliveira. O direito à memória: a história oral de mulheres que lutaram contra a ditadura militar (1964 - 84). Revista Tempo e Argumento, Florianópolis, v. 5, n.10, jul./dez. 2013. p. $108-132$.

\section{DOI: $10.5965 / 2175180305102013108$}

http://dx.doi.org/10.5965/2175180305102013108 


\title{
Memory right: the oral history of women who fought against military dictatorship (1964 - 84)
}

\begin{abstract}
This article aims to present historiographical research that addressed women's testimonies about the fighting against the brazilian military dictatorship. Among them, also is presented my PhD research, developed from life stories of women who have resisted oppression, quietly, having rarely been recognized by society as historical subjects. Nowadays testimony oral history exerts a major role in denunciation and quest for memory right especially of those that still not visible to the public, including women, often seen as outsiders in the political space. Their accounts reveals multiples forms of action in the fight against authoritarianism, showing that public and private are not exclusionary nor opposites.
\end{abstract}

Keywords: Testimony oral history. Memory right. Women. Military dictatorship. 
Sob a história, a memória e o esquecimento. Sob a memória e o esquecimento, a vida. Mas escrever a vida é outra história. Inacabamento.

Paul Ricœur

\section{Introdução}

Assiste-se hoje, no Brasil e em vários países da América Latina, a um processo gradativo de conquista e devolução da palavra aos que foram perseguidos durante o período da ditadura militar. Temas como verdade, justiça e reparação ganham força, principalmente depois da criação da Comissão da Verdade, em 2012, em que se confrontam versões e diferentes memórias.

A memória testemunhal ganha cada vez mais importância, não como lamento e vitimização de quem se propõe contar a própria história, mas como possibilidade de digerir uma experiência dolorosa que marcou toda a sociedade entre 1964 e 1984. A campanha pela abertura dos arquivos e a intensificação das pesquisas com a história de vida de pessoas que foram presas, torturadas, exiladas oude alguma forma perseguidas pela repressão implica entender dois processos distintos e complementares: o direito e o dever de lembrar os traumas psicológicos e físicos e de sobre eles falar, e o direito ao registro, à interpretação e à análise histórica desse período traumático no Brasil.

Os que se dispõem a falar sobre suas dores assumem a tarefa de contar sua experiência particular emaranhada a outros destinos em comum e reforçam as vozes que se querem fazer ouvir. Trata-se da verdade da memória, que reúne elementos dispersos, apresentando ao mesmo tempo retrato pessoal, coletivo e identitário, por meio dos quais homens e mulheres reconstituem sua própria unidade e identidade num tempo que a narrativa revela complexamente subjetivo, emotivo e racionalizado. Não se trata somente da "verdade histórica", crítica, distanciada pelo método, decifração e análise 
dos signos, mas da "verdade do testemunho", dinâmica, incompleta e sempre presentificada.

A história oral tem contribuído, neste sentido, para dar a conhecer grupos excluídos de registros escritos e inscrever no relato historiográfico vozes múltiplas e silenciadas. Palavras de ordem criadas pelos regimes autoritários e mantidas por seus defensores foram usadas para evitar a possibilidade de se falar das barbaridades praticadas, dar-lhes outros nomes e de, ao lembrá-las, identificar seus autores, significados e consequências no presente. Marcados como subversivos, antipatriotas, aniquilados em sua integridade física e mental, os opositores dos regimes autoritários foram suprimidos em palavras e em existência. Na luta pela validação de memórias diferenciadas contra os estereótipos criados e, principalmente, para falar dos traumas sofridos, o testemunho dos que resistiram à opressão e foram silenciados tenta abrir espaço no clima de indiferenças; ganhar importância como denúncia, responsabilização e reparação.

Neste sentido, a história oral ganhou caráter testemunhal, termo defendido por José Carlos Sebe Bom Meihy, colaborando para trazer a público os sofrimentos mais íntimos e ignorados no contexto das tragédias coletivas, como o autoritarismo e o silenciamento por ele produzidos:

É exatamente o desenrolar de processos como deslocamentos, exílios, catástrofes, que implicou a formulação deste novo gênero, ou seja, da busca de fundamentos desse novo campo, o da história oral testemunhal. [...] é preciso olhar situações ou de grupos em que o colaborador envolvido participou de forma traumática, como vítima, de alguma circunstância marcante. Não se fala apenas de casos políticos, pois há grupos que sofreram com terremotos, enchentes, pestes, enfim, situações que produziram traumas específicos. Mudanças do comportamento mnemônico em face de tragédias são importantes para a requalificação da identidade e, mais do que isso, do estabelecimento de políticas públicas (MEIHY, 2010).

No caso das mulheres, em especial, os relatos orais apresentam-se como caminhos para que elas possam entrar em cena na chamada "grande história", em que geralmente estiveram invisíveis, dela foram relegadas à vida privada, ou simplesmente situadas nos bastidores de lutas atribuídas aos homens. Mesmo na resistência contra o regime 
autoritário, não só os perpetradores trataram de calá-las, mas a própria esquerda ligada à luta armada poucas referências fez a elas. O imaginário sobre a guerrilha é, muitas vezes, masculinizado e viril, reforçado por inúmeros trabalhos que pouco tratam da presença feminina nos quadros dos grupos clandestinos que se opuseram à ditadura militar. ${ }^{1}$

Dentro dessa perspectiva é que pretendo apresentar a contribuição de pesquisas que utilizaram a história oral na tentativa de ampliar as vozes de mulheres como testemunhas neste momento em que as feridas são necessariamente tocadas para que a memória possa nos libertar da história, como diria Jacques Le Goff (1997). Inicio com a apresentação de alguns trabalhos que contribuem para o conhecimento e o reconhecimento da participação feminina na luta armada durante a ditadura militar. Mais do que isso, destaco a atuação quase invisível de mulheres que agiram "nas sombras", deslocando-se entre o espaço privado/familiar e público, na luta pela vida e proteção de seus familiares e amigos. Este aspecto da solidariedade afetiva e cotidiana, fora das organizações de guerrilha, constituiu a parte central da pesquisa por mim realizada para o doutorado na Universidade de São Paulo, em 2012, com um grupo de parentas e amigas de homens envolvidos no enfrentamento direto à ditadura militar brasileira ${ }^{2}$.

Compartilhar as lembranças femininas não significa aqui complementar uma história masculina, mas democratizar a memória, perceber suas fissuras e inúmeros significados que o ato de sobreviver ao trauma coletivo representou.

\footnotetext{
${ }^{1}$ Há extensa bibliografia sobre a guerrilha no Brasil, principalmente sobre o ano de 1968, com destaque para a ação masculina. Somente para citar os trabalhos mais clássicos, indico para leitura as obras 1968: $a$ paixão de uma utopia (1988), de Daniel Aarão; O Fantasma da Revolução Brasileira (1994), Marcelo Ridenti; 1968: o ano que não terminou (1998) e 1968: o que fizemos de nós (2008), do jornalista Zuenir Ventura. Em especial sobre o movimento estudantil, a guerrilha e seu caráter combativo, sugiro a leitura de Combate nas Trevas (1987), de Jacob Gorender; 1968 : O Diálogo É a Violência - Movimento Estudantil e Ditadura Militar no Brasil, de Maria Ribeiro do Vale (2008) e 1968: eles só queriam mudar o mundo (2008), de Regina Zappa.

${ }^{2}$ A tese de doutorado acaba de ser publicada em ebook com o título Osasco 1968: a greve no masculino e no feminino, pela Editora Pontocom (2013), trata da memória coletiva e das relações de gênero de operários, estudantes-operários, guerrilheiros e suas companheiras, donas de casa, estudantes, irmãs, esposas e guerrilheiras, que atuaram na luta contra a ditadura civil-militar.
} 


\section{Gênero e história oral}

O encontro entre o feminino e a história oral no processo de redemocratização revela que o político faz parte do cotidiano e do privado, rompendo com a suposta divisão binária entre o mundo dos homens (público) e o mundo das mulheres (subjetivo), promovendo o questionamento sobre o funcionamento de instâncias consideradas especialidades femininas: a organização da família, a perpetuação e a transmissão de valores culturais, os afazeres cotidianos, a emoção e os laços afetivos. Michelle Perrot já havia chamado a atenção para o fato de essa fronteira ser superficial e esses espaços se inter-relacionarem, assim como para as especificidades das práticas femininas:

As mulheres não são passivas nem submissas. A miséria, a opressão, a dominação, por reais que sejam, não bastam para contar sua história. Elas estão presentes aqui e além. Elas são diferentes. Elas se afirmam por outras palavras, outros gestos. Na cidade, na própria fábrica, elas têm outras práticas cotidianas, formas concretas de resistência - à hierarquia, à disciplina - que derrotam a racionalidade do poder, enxertadas sobre uso próprio do tempo e do espaço. Elas traçam um caminho que é preciso reencontrar. Uma história outra. Uma outra história (PERROT, 2006, p.212)

Para ela, se à mulher não coube o poder institucional na maior parte do processo histórico, seria possível falar de seus diversos poderes cotidianos e familiares e do quanto eles afetariam as relações sociais e políticas, mesmo quando invisíveis aos olhos da sociedade e de parte da historiografia.

No Brasil, muitos trabalhos abordaram a história das mulheres, ou de gênero, a partir da visibilidade das relações entre o feminino e o masculino, que, socialmente, ao longo da História, ${ }^{3}$ ora poderiam se complementar, ora se confrontar. Colocaram em

\footnotetext{
3 Para citar apenas alguns deles, destaco os trabalhos precursores da socióloga Heleieth lara Bongiovani Saffioti, A mulher na sociedade de classes: mito e realidade (1969), e o da historiadora Maria Odila Leite da Silva Dias, Quotidiano e poder em São Paulo no século XIX, publicado em 1984; o livro A condição feminina no Rio de Janeiro, século XIX: antologia de textos de viajantes estrangeiros, do mesmo ano, de Miriam Moreira Leite; a obra Do cabaré ao lar: a utopia da cidade disciplinar, Brasil 1890-1930, de Margareth Rago, publicado em 1985, além dos trabalhos de Eni de Mesquita Samara, As mulheres, o poder e a família: São Paulo século XIX, e de Magali Engel, Meretrizes e doutores: saber médico e prostituição no Rio de Janeiro, ambos de 1989. Na década de 1990, foram importantes os livros de Elizabeth Souza Lobo, A classe operária tem dois sexos, publicado em 1991; de Marina Maluf, Ruídos da Memória, publicação de 1995; História das mulheres no Brasil, coordenado por Mary Del Priore, e Gênero em debate: trajetória e
} 

pesquisas trataram da condição feminina no contexto da ditadura militar, resultado do silenciamento promovido pelo regime autoritário à resistência social e pela própria visão histórica predominante, incapaz de enxergar nas mulheres a atuação política. 0 pioneirismo coube a Albertina Oliveira Costa, em sua obra Memórias de Mulheres do Exílio, publicado em 1980, em pleno regime de exceção, utilizando os procedimentos da história oral de vida a partir da experiência de militantes da luta armada, que foram presas, torturadas e exiladas.

Com o fim do longo período de autoritarismo no Brasil, o tema sobre o combate à ditadura foi e continua sendo explorado por trabalhos que colocaram em evidência o imaginário de virilidade e coragem, aspectos culturalmente atribuídos à geração da década de 1960. O movimento estudantil e cultural por todo o País, as greves operárias de Contagem e Osasco, em 1968, e o movimento sindical em São Bernardo do Campo no final da década de 1970, além da luta clandestina, continuam a ser estudados enfaticamente, principalmente diante do apelo da sociedade civil em torno das comissões de desaparecidos, da pressão pela abertura de arquivos e da nomeação de membros para a Comissão da Verdade, pela presidente Dilma Rousseff, em maio de 2012.

O processo de redemocratização permite passar a limpo muitas histórias que emergem do silenciamento político e até mesmo de gênero. O trabalho da Comissão da Verdade, assim como pesquisas com testemunhos femininos, tornaram mais visível a presença de mulheres em meio a estudantes, presos, torturados, militantes da luta armada e exilados. Muitas vezes pouco exploradas nos documentos escritos, seja dos órgãos de repressão ou de registros dos grupos políticos, suas experiências começaram a ser trazidas pelas narrativas orais que passaram a constituir fontes historiográficas novas, repletas de subjetividade. Os relatos dialogam com a visão padronizada da "grande história masculina", mostrando fissuras, críticas, discordâncias por meio das palavras das 

participantes de diferentes organizações de guerrilha pudessem ser conhecidos, democratizando informações e interpretações sobre o passado. Mais do que complementar o que seria considerado experiência masculina, a história oral de vida dessas mulheres foi o meio pelo qual elas puderam expor e avaliaras relações com seus companheiros, a hierarquia de poder entre os gêneros dentro das organizações e o descompasso entre o ideal feminista e a concepção política da esquerda brasileira. Com o estudo em torno da memória, a história oral teria iniciado sua contribuição no alargamento sobre os significados e efeitos da violência perpetrada pela ditadura sobre diferentes setores da sociedade brasileira. Ampliou-se a noção de sujeito histórico, não mais entendido de forma universal, mas humanizado em suas subjetividades e singularidades sexuais, étnicas e sociais.

Na medida em que a memória intersubjetiva ${ }^{4}$ vai sendo partilhada pela oralidade feminina, constrói-se continuamente uma comunidade de narradoras que buscam uma comunidade de escutadores, pelo desejo de torná-los eco daquilo que elas se dispuseram a contar e que durante muito tempo permaneceu vivo na memória familiar ou nas rodas de amizade que mantiveram. Como afirmou Michael Pollak:

O longo silêncio sobre o passado, longe de conduzir ao esquecimento, é a resistência que uma sociedade civil impotente opõe ao excesso de discursos oficiais. Ao mesmo tempo, ela transmite cuidadosamente as lembranças dissidentes nas redes familiares e de amizades, esperando a hora da verdade e da redistribuição das cartas políticas e ideológicas (POLLAK, 1989, p. 4).

A memória feminina proibida, clandestina ou ignorada durante a ditadura militar, procura hoje conquistar o espaço público com suas reivindicações e cada vez mais assume a disputa com outros discursos que até então trataram de desqualificá-la.

\footnotetext{
${ }^{4}$ Utilizei o termo intersubjetividade com base na oralista Luísa Passerini (2006), por considerar que as diferentes subjetividades são construídas na coletividade, como resultados contínuos das relações entre as individualidades, ao mesmo tempo em que estas promovem a identidade do grupo. As narrativas orais, segundo ela, têm caráter intersubjetivo, pois a memória pessoal é antes coletiva.
} 

transmissão da experiência coletiva, de um passado que não passou, que ainda é ferida aberta. Por isso, a necessidade de insistir no esclarecimento dos crimes e dos traumas que afetaram suas vidas com toda a carga de emoções, todas as frustrações e sofrimentos.

Esse processo doloroso de tocar em feridas e traumas individuais e coletivos não significa dar voz às mulheres que vivenciaram o período do autoritarismo, mas oferecerIhes ouvidos atentos, prontos a perceber as diferenças dentro da diferença, múltiplos sentidos nas chamadas "memorias di cucina”, como afirma Luísa Passerini ${ }^{5}$. Abordar suas histórias durante o período do regime autoritário não é tratar de uma mulher única, submissa aos homens, nem entendê-las somente em oposição a eles. É abordar uma variedade de memórias que as colocam, muitas vezes, lado a lado com eles nas lutas cotidianas e políticas.

\section{A presença feminina na luta armada}

A presença feminina ao lado dos homens na luta armada não foi insignificante. Segundo Marcelo Ridenti (1990), a participação feminina seria de $18 \%$ nos quadros guerrilheiros, sendo elas $20 \%$ dos militantes no Araguaia ${ }^{6}$. Alguns trabalhos desenvolvidos com ex-guerrilheiras mostraram suas diferentes origens: estudantes universitárias, frequentadoras de bares e lugares de debates organizados pelo movimento estudantil ou pela Igreja ligada à Teologia da Libertação.

Ana Maria Colling (1997), que entrevistou seis militantes da luta armada, procurou compreender como a repressão criou, pelo discurso, o conceito de "mulher subversiva"

\footnotetext{
${ }^{5}$ Passerini afirma que a memória feminina é alimentada pelas conversas mantidas no espaço privado, na casa, na família. Mesmo quando invisível ao político e ao mundo masculino, as experiências das mulheres continuam a ser significadas e valorizadas por elas.

${ }^{6}$ Pesquisas como a realizada por Elisabeth F. Xavier Ferreira (1996) revelam que, das duzentas mil pessoas envolvidas em processos, 578 foram denunciadas; a maioria, originária da classe média.
} 

série de desvios quanto à esperada conduta feminina, rompendo com o imaginário de mulheres ignorantes, recatadas e frágeis.

As narrativas das entrevistadas, que foram presas e torturadas, revelaram o quanto, para os órgãos da repressão, a militante representava de subversão, e por isso deveria ser controlada e enquadrada.

Para a repressão, a mulher militante será definida sempre como — puta comunista'. É Simone quem afirma; "eles usam uma expressão que é constante, eles não usam o teu nome, eles usam sempre - puta comunista". A imagem da mulher como anjo ou demônio está muito presente. O anjo corporificado em Maria, pura e santa, é a mulher tradicional, a mãe assexuada, restrita ao mundo privado do lar; e o demônio é corporificado em Eva, que levou o primeiro homem ao pecado, portanto desviante e corrompedora, sexuada e sedutora. É neste segundo modelo que se enquadra a militante comunista (COLLING, 1997, p. 37).

Ao construir a imagem da mulher politizada como desvio, a repressão procurava reafirmar que o sexo feminino seria incapaz das decisões políticas e não teria vontade própria. Deveria ser tutelada pelo homem. Nos registros das prisões, elas eram sempre apresentadas como esposas, filhas, amantes e irmãs de homens procurados pela polícia. Dificilmente tinham seu nome em destaque ou se acreditava que teriam sido tão ousadas. Se elas estavam no movimento estudantil e, principalmente, nos grupos armados, isso deveria ser atribuído a questões de manipulação ou desvio, por romperem com a moral tradicional.

A repressão tratou de construir, em torno das que pegaram em armas, um sujeito unitário que foi compartilhado pela imprensa e pela sociedade em geral. Eram constantes as imagens nos noticiários sobre loiras terroristas, tratadas como drogadas ou "malucas". Muitas, inclusive, foram internadas em manicômios, por se terem deixado seduzir pelo comunismo. 
O trabalho de Olívia Rangel Joffily (2005) contribuiu para o esclarecimento sobre a tortura e o olhar dos perpetradores sobre a condição das guerrilheiras. Joffily tratou das ações e prisões dessas militantes e, principalmente, do olhar e do tratamento a elas dispensado pelo torturador. O fato de serem consideradas "sexo frágil" não diminuiu, mas intensificou ainda mais a violência sobre seus corpos, para reprimir a escolha de terem agido "como machos" ao pegarem em armas?.

A condição de comunistas era associada à imoral socialização de mulheres como propriedade coletiva, o que permitiria o respeito às que haviam ousado tomar o espaço público, abandonar desonrosamente o lar - e legitimaria, portanto, a humilhação e a violação de seus corpos nos porões dos órgãos de repressão. ${ }^{8}$

Entrar para a luta armada lançou-as para dentro do campo da ação política, engajando-se no enfrentamento ao governo militar. Insurgiram-se, de forma consciente ou não, contra os princípios da hierarquia de gênero de sua cultura, antecipando-se ao movimento feminista que só teria força no Brasil em meados dos anos de 1970, além de reconstruírem sua identidade contra os estigmas criados pela memória hegemônica do Estado militar. Recentemente, trabalho de Margareth Rago (2013) procurou dar destaque a militantes feministas na década de 1970, como a ex-presa política Crimeia Schmidt e a antropóloga Maria Lygia Quartim de Moraes. Assim como no caso das demais guerrilheiras, suas histórias de vida colaboraram para desmistificar a luta armada e a militância política como ações masculinas e demonstrar as relações de hierarquia, conflito ou solidariedade entre os gêneros.

\footnotetext{
${ }^{7}$ Podem-se citar ainda os trabalhos de Luiz Maklouf Carvalho, Mulheres que foram à luta armada, publicado em 1998, e de Susel Oliveira da Rosa, Mulheres, ditaduras e memórias: não imagine que precise ser triste para ser militante (SP: Intermeios, 2013). Os trabalhos trazem entrevistas realizadas com mulheres que participaram de diferentes grupos armados.

${ }^{8}$ As narrativas de Ferreira (1996), Colling (1997), Carvalho (1998) e Joffily (2005), assim como os relatos das mulheres por mim entrevistadas, estiveram repletos de exemplos do tratamento dispensado pelo regime à figura da guerrilheira: jornais construíam a imagem da loira dos assaltos - insinuante - das quais a mais famosa foi Maria Aparecida Costa, militante da ALN; casos de chantagem envolvendo a perda de filhos e maridos; tentativas de suicídio, como os casos de Inês Etiene, membro da VPR que denunciou Casa da Morte de Petrópolis, ou de Maria Auxiliadora, militante do COLINA, que acabou com a própria vida no exílio, em decorrência das sequelas psicológicas das torturas. Ou ainda o caso de Sônia Maria de Moraes, cuja morte foi provocada pelas barbaridades perpetradas contra ela na prisão.
} 
Além disso, as narrativas das entrevistadas revelaram como, muitas vezes, elas se viram divididas numa grande contradição: como geradoras "naturais" da vida, precisaram decidir o momento de tirá-la no enfrentamento armado. Essa condição nova desconstruiu os valores e atributos considerados inatos ao feminino, em oposição ao masculino, mostrando como força, virilidade e coragem não eram exclusivas de um segmento social ou sexual.

Aspecto importante apontado por Colling, além do rompimento com o imaginário sobre a mulher reservada ao espaço doméstico, é o fato de que, para serem aceitas, algumas guerrilheiras continuaram contribuindo para a desigualdade de gênero. Para conseguirem assumir postos de comando nas organizações - feito raro -, elas aceitaram e assumiram o discurso masculino de que o lugar de comando no mundo político mesmo nas organizações de esquerda - seria reservado aos homens e, portanto, passaram a atuar como figuras desprovidas de "qualidades femininas".

A questão do consentimento é central no funcionamento de um sistema de poder, seja social ou sexual, devendo ser objeto de estudo também a dominação masculina como dominação simbólica, que supõe a adesão das próprias dominadas a categorias e sistemas que estabelecem a sujeição (COLLING, 1997, p.4).

A adesão aos valores masculinos tornou-se perceptível em práticas e comportamentos das militantes, que se destituíram de valores considerados femininos e fracos, igualando-se aos guerrilheiros - abrindo mão de relações afetivas ou de filhos, por exemplo - para assumir postos de liderança quanto a decisões ou ações. A diferença de gênero, nesse caso, não se apresentou como direito defendido por algumas delas, considerando que para ser respeitadas por seus companheiros - e até pelos seus torturadores - elas deveriam agir "como homens", mostrando coragem e ousadia, atributos considerados masculinos. Elas se comportaram, em certa medida, como sujeitos assexuados ou masculinizados, apresentando postura dura, séria, rígida, numa atitude paradoxal: romperam com preconceitos com relação ao papel feminino na sociedade, porém, mantendo os preconceitos conservadores nos grupos armados. 


\section{Participação invisível: a solidariedade feminina}

Além das mulheres que pegaram em armas, houve ainda um número incontável delas que participou de forma ainda mais invisível em acontecimentos não devidamente explorados pela historiografia e desconhecidas da sociedade brasileira: atuaram dentro de casa, acolhendo pessoas, escondendo armas, objetos e documentos, levando mensagens para membros dos grupos clandestinos ou circulando entre a cadeia e as famílias, como intermediárias.

Maria Cláudia Badan Ribeiro (2011) também trabalhou com a memória oral de mulheres, procurando ouvir não apenas as que haviam atuado diretamente, mas agido à margem e na retaguarda da Ação Libertadora Nacional (ALN), no que ela chamou de “socorro vermelho", oferecendo casas, remédios, informações e documentações falsas aos membros da organização.

Invisíveis para certa historiografia que tratou da guerrilha, elas eram recrutadas majoritariamente entre o movimento estudantil e exerciam tarefas fora da organização, expandindo ideais, tentando ganhar adeptos em seus locais de trabalho, preparando expropriações de bancos, repassando informações. Segundo a historiadora:

Não há no Brasil bibliografia específica sobre esse aspecto, de como a luta contra a ditadura utilizou-se da rede legal de militantes e simpatizantes tendo penetração junto à população economicamente ativa. Não temos, portanto, um número para dimensionar quantas e por quanto tempo essas mulheres desempenharam esse papel, considerando-se também que esse trabalho foi realizado sob nome falso e muitas vezes sem registro em carteira (RIBEIRO, 2011, p. 164).

Muitas delas construíram redes de solidariedade imperceptíveis aos pesquisadores, à sociedade e aos próprios homens, seus companheiros. Foi o que minha pesquisa de doutorado pela Universidade de São Paulo demonstrou com maior clareza. Entre os anos de 2008 e 2012 realizei entrevistas com 11 mulheres, procurando ampliar ainda mais o olhar sobre as ações femininas, as ainda mais imperceptíveis, que aconteciam no espaço privado da família. Entre elas estavam esposas, irmãs, sobrinhas e amigas de operários participantes de uma greve ocorrida em 1968 na cidade de Osasco e 
pautaram necessariamente suas atitudes, nem tampouco a militância em partidos ou agrupamentos clandestinos. Pelo menos não no início de suas vidas, como donas de casa ou estudantes secundaristas. As narrativas sobre suas experiências permitiram perceber a existência de outra ética da solidariedade, nascida do afeto para com maridos, parentes e amigos, que também as lançou no mundo político, num ativismo emocional não menos importante que a militância ideológica. Ética que forjou a reconstrução das subjetividades, marcadas pela clandestinidade, o anonimato, o desvio, num enfrentamento à moralidade conservadora.

Aspecto novo trazido por elas, a subjetividade, revelou que os sentimentos, a paixão, a proteção da família - principalmente dos filhos - também devem ser levados em conta no processo histórico para compreender as relações políticas e de gênero, além dos efeitos violentos sobre as famílias daqueles que foram perseguidos pela ditadura militar. Forçadas a sair do espaço da casa e transitar pelas cadeias e delegacias ao mesmo tempo em que lidavam com a casa e os filhos; enfrentar os homens que torturavam e ameaçavam seus entes queridos e, de forma mais radical, pegar em armas, transformouas em outsiders da ordem, num constante processo de desterritorialização e reterritorialização, na trajetória entre o público e privado, de fronteiras tênues, marcadas por rompimentos afetivos, estigmatizações e reformulação ou acúmulo de novas identidades.

Suas ações movidas pela paixão ampliaram ainda mais as táticas de resistência à ditadura, praticadas por elas e muitas vezes desconhecidas ou desvalorizadas como ações históricas ou políticas. Oferecer a casa às reuniões dos militantes; usá-la como esconderijo; oferecer seu espaço mais íntimo, familiar, para guardar armas e documentos; alimentar clandestinos; promover festas de aniversário no Presídio Tiradentes,

\footnotetext{
${ }^{9}$ A greve, que durou praticamente um dia, na empresa Cobrasma, sofreu brutal intervenção e alterou radicalmente a vida dos envolvidos no processo, de forma direta ou indireta: solidão, desemprego, prisões, clandestinidade, invasão de casas, tortura e o exílio geraram traumas masculinos e femininos.
} 
próprio corpo, muitas vezes insuspeito porque feminino, para levar bilhetes de presos e seus familiares ou recados das organizações, para seduzir perpetradores de seus entes queridos e arrancar benefícios. As mulheres arriscaram-se.

O corpo feminino, sensualizado e sedutor, ou a maternagem (os filhos, levados pela mão ou no colo, reforçando a figura da mãe protetora e cuidadora), foram artifícios - conscientes ou não - usados por elas na tentativa de adentrar as delegacias, dialogar com os soldados e autoridades, para tirar vantagens.

O vazio deixado pela repressão às lutas tradicionais, principalmente a partir de 1968, promoveu a demanda de ações públicas das mulheres, acostumadas a se reservar ao mundo privado. Estas, então, desafiaram a ordem estabelecida, transformando a sua própria vivência. A ditadura destruiu os meios de diálogo e interlocução, impondo a necessidade de novos mediadores. Ao assumirem esse papel, romperam com a hierarquia de sexo e atuação política e deixaram falar mais alto o espírito de iniciativa e o senso de oportunidade.

Beatriz Sarlo (2005) apresentou o panorama em que penso ter sido traçado o caminho por parte das mulheres nos anos 1960 e 1970. Ela afirmou que nesse período, na América Latina, elas tenderam a se apresentar não como sombra dos outros, nem como sujeitos passivos e submissos e sim como produtoras de discursos e práticas próprios que promoveram outro olhar sobre o passado e o presente. Para ela, a ação política não se restringiu ao ideológico e institucional, mas a intervenções reinventadas pela razão e pela paixão. A política como paixão descreve a relação das mulheres com a esfera pública dentro de um espaço delimitado por certos traços da "imagem feminina":

Semelhante a quem se vinga do que foi rotulado como o "puramente feminino", as mulheres reorganizaram temas ideológicos em novas formas de prática e de discurso que, muito obviamente, não obedecia a nenhum pressuposto, mas nasceu da necessidade de trabalhar com o que a cultura havia estabelecido como campo de mulheres e legitimou como preocupações femininas. As mulheres adotaram o que pode ser 
entendido como uma estratégia bricolage, produzindo novos assuntos públicos a partir de antigos papéis e funções tradicionais. Se a sociedade definiu o privado como a quintessência da esfera feminina, as mulheres transformaram os assuntos privados em debates políticos e em intervenções (SARLO, 2005, p.188-189).

Sentimentos considerados tipicamente femininos, como amor, caridade e fraternidade, tornaram-se a base de seu comprometimento público. Ganharam novos significados no âmbito da política para defender a justiça, a proteção aos presos e modelarem o enfrentamento ao regime. Esse recurso à bricolagem, ou seja, à prática de criar novos papéis a partir dos tradicionalmente atribuídos, tornou-se fundamental na história feminina para lidar com as perdas e amenizar o impacto da violência e das perdas em suas vidas e de suas famílias. Sentimentos de amor e piedade, considerados naturais à função das mães e esposas, foram traduzidos por atos de solidariedade nas prisões e nas ruas, reivindicações de justiça e mobilizações. Mais tarde, na luta pela anistia aos seus companheiros, integraram-se ao processo nacional de reivindicação pela democracia que marcou o final da década de 70.

Elisabeth Jelin (1994) entendeu essas atitudes como construção de uma "política de afeto", enquanto Judith Butler (2003) apontou como as estratégias femininas podem se constituir numa "performance de gênero" a serviço do jogo político na tentativa de negociar. Não só a entrada feminina no espaço político, público e militante pode explicar ou marcar as táticas de luta criadas pelas mulheres contra a opressão política e de gênero. Os testemunhos das entrevistadas durante minha pesquisa demonstraram que assumir o papel feminino imposto pela sociedade se tornou uma grande arma para burlar os limites e proibições, mesmo em "território inimigo" (delegacias e prisões). Suas narrativas revelaram táticas de esperteza e negociação constantes. Pequenos planos, como oferecer café aos soldados e tratamento amigável àqueles que vigiavam suas casas, conseguiram impedir, muitas vezes, que suas casas fossem invadidas ou garantiram que a vida de seus familiares fosse poupada. Muitas vezes, crianças de colo eram trazidas diante de militares e delegados (como o temido Luís Paranhos Fleury) para reforçar a ideia de mães zelosas, esposas frágeis, submissas e ignorantes, a fim de conseguir 
para extrair pequenas vitórias sobre os algozes de seus entes queridos. A memória feminina vasculha as lembranças mais íntimas e expõe atitudes corajosas e ousadas.

No espaço íntimo da casa, durante a madrugada, a maioria delas revelou como contribuíram decisivamente para o apagamento de provas contra seus companheiros, queimando documentos, enterrando-os no fundo dos quintais, ou até mesmo comendoos para não deixar rastros. Também escondiam armas sob as camas e faziam a comida que alimentaria muitas vezes pessoas desconhecidas que pernoitavam em seus lares, invadindo sua vida privada e colocando sua família em perigo.

A busca por seus parentes e amigos, o abandono, a falta de compreensão dos acontecimentos, o enfrentamento de delegados, a presença nas salas de interrogatórios, os cafezinhos, tudo que se iniciou de forma espontânea colaborou para o crescimento e a recriação de formas cada vez mais criativas de agir nas cadeias, assim como de maneiras mais organizadas e coletivas de manifestação, nos anos 1980, nas ruas e praças.

Conseguiram confundir os algozes com sua coragem e determinação, ao mesmo tempo em que se apresentavam frágeis, indefesas. Justamente nessa fragilidade e nos padrões construídos para o feminino é que articularam sua defesa e proteção, procurando interferir no plano perigoso da repressão, nos espaços impenetráveis da tortura e da prisão. Investiram-se do papel tradicional, respaldadas no imaginário coletivo, de cuidadoras, defensoras das famílias e preservadoras da memória como sua atribuição social, fortalecendo sua luta.

Valendo-se desse papel de reserva de memória, as narradoras relembraram as violências cometidas contra outros, denunciando as atrocidades contra tantos semelhantes; falaram dos amigos e parentes mortos, dos ausentes e do quanto suas vidas foram ceifadas injustamente. As entrevistadas revelaram redes de solidariedade que se formavam entre os vizinhos toda vez que se noticiava que alguém havia morrido ou “desaparecido": transmissão rápida da notícia, mobilização, visitas às casas, coleta de 
Foi grande a transformação coletiva protagonizada por elas. Por seu formato nãoviolento, “maternal”, por ser gesto "feminino" e, portanto, considerado despolitizado, sua participação dificultou o combate do Estado. Afinal, como o regime poderia lidar com o fato de se sentir ameaçado por um grupo de mulheres desarmadas, e que não praticavam qualquer ação violenta? Agredi-las enquanto visitavam seus companheiros, quando exigiam os corpos de seus parentes ou os direitos da comunidade seria o mesmo que negar o que as definia como mulheres.

Na década de 1970, elas ampliaram suas ações: ocuparam praças com mesas para recolher assinaturas pela Anistia, pacificamente, como era considerado próprio a uma "mulher decente" e "coitada"; utilizaram o espaço das igrejas com sua presença por vezes silenciosa, como ocorreu na Praça da Sé; reuniram vizinhos em casa para criar redes de solidariedade; exigiram creches e postos de saúde para seus filhos. Dentro do que se poderia esperar das relações de gênero numa sociedade tradicional, elas construíram sua força subversiva contra os regimes autoritários, utilizando os atributos a elas imputados. Sob a repressão e o silenciamento ditatorial; sob os discursos masculinos dos operários, estudantes e guerrilheiros; sob as militantes políticas e as guerrilheiras; mesmo invisíveis como seres políticos, muitas vezes, elas estiveram presentes numa luta sinuosa, desviante e quase imperceptível em oposição ao regime que atingiu suas famílias e a suas vidas. E incomodaram.

Diferente das mulheres entrevistadas por Colling, Ferreira, Joffily e Ribeiro, as que se dispuseram a me contar suas histórias, em sua grande maioria, não pegaram em armas nem pertenceram ao "socorro vermelho", a que se referiu Ribeiro, pois não chegaram a ser recrutadas pelas organizações, nem se envolveram num movimento coletivo organizado. Pelo menos até 1968, sentiam-se “abandonadas" pelos maridos, sozinhas e com medo, começando sua luta com ações individuais e espontâneas, até se identificarem com outras ativistas e se fortalecerem. 
Embora não tivessem sido presas, sofreram o trauma da invasão de suas casas, o sequestro e morte de pessoas amadas; sentiram-se vigiadas e abandonadas, sozinhas e sem rumo. Elas permitiram ou tiveram que permitir que os problemas da vida nacional ocupassem espaço em suas vidas, invadissem suas preocupações cotidianas, se misturassem ao tempo doméstico, reestruturando-o. O íntimo, o cuidado com os seus sua função marcadamente social, naquele momento - não só tomou gradativamente o espaço público como, ousadamente, violou territórios proibidos do cárcere e da dor.

Nesse processo foram, enfim, também torturadas.

\section{A experiência feminina e a democratização da memória}

Muito pouco se falou ainda sobre essas experiências e seus significados para essas mulheres. Seus traumas são traumas coletivos, históricos. É preciso que neste momento de "memórias reveladas", essas histórias se tornem públicas e conhecidas por meio de trabalhos historiográficos, debates públicos e os mais diferentes meios de comunicação. Silvia Salvatici chamou a atenção para a importância da história oral de mulheres para o processo democrático:

As pesquisas realizadas a partir da perspectiva de gênero ressaltaram a necessidade de um discurso público capaz de admitir e acolher as narrativas de diferentes sujeitos sociais, a necessidade de um arcabouço público no qual as memórias de todos possam ser reconhecidas e, ao mesmo tempo, elas próprias possam se reconhecer. A História oral de mulheres tem destacado a urgência do "processo de democratização da memória”, que é a condição básica para as democracias contemporâneas" (SALVATICl, 2005, p. 36).

Além da militante política e da guerrilheira, é preciso lembrar aquela que atuou no espaço da casa e na família, circulando entre o espaço do sindicato, da igreja e do lar, ou ainda no simbólico território vazio da incerteza e do isolamento, fora e dentro do País. Muitas delas tiveram que sair de casa e ser acolhidas por parentes e amigos, com medo da vigilância sobre seus companheiros. Outras tiveram que se esconder em cidades que 
notado da mediação e da solidão, procurando descrever e transmitir o que até então havia permanecido nas memórias sob a história oficializada do regime autoritário e a memória masculina e viril da greve, da guerrilha e da luta política. Suas lembranças permaneceram subterrâneas, não no sentido dormente e latente, mas na condição do que Luísa Passerini chamou de fiume carsico (rios subterrâneos) ou memoria di cucina, trocada continuamente nos espaços da casa e da família, e cada vez mais, lado a lado com seus companheiros e filhos. ${ }^{10}$

Para o estudo da luta feminina contra a ditadura militar nos 20 anos de repressão, o movimento de "sair das sombras" deve ser considerado. Trata-se do deslocamento da ideia de centro (masculino) e periferia (feminino) na História, pois as narrativas das entrevistadas colocaram em evidência aspectos pouco considerados no debate político e historiográfico sobre a luta armada e outras formas de resistência. Considerar suas experiências permite a elas também se olhar e descobrir como sujeitos históricos da mesma vivência e se deslocar para o centro da História.

A atuação dos grupos armados, assim como de inúmeras manifestações de resistência contra o regime militar, foi resultado das relações de gênero, de solidariedade, conflito, medos e vontades; exercícios de micropoderes femininos que se alinharam e pactuaram com os homens para resistir ao sofrimento. Como afirmou Michel Foucault (1997), o exercício do poder se estabelece nas mais íntimas instâncias e não se confunde apenas com opressão, mas também com a capacidade de resistência e criação. Não é apenas consentimento e submissão; é múltiplo, positivo e produtor de saberes. As ações masculinas e femininas no enfrentamento do poder disciplinador do Estado foram formas de rearticulação de poderes e não apenas seu depositório sobre corpos passivos e disciplinados, essencializados.

\footnotetext{
${ }^{10}$ Este termo foi usado e explicado pela oralista no curso Memória e Subjetividade, ministrado na Universidade de São Paulo, entre os dias 8 e 10 de agosto de 2011. Para ela, expressaria melhor a memória viva e contínua do que o termo " memória subterrânea", utilizado por Michael Pollak.
} 
Na quase ausência de espaços para a memória durante os 20 anos da ditadura militar, hoje o corpo e a voz passam a ser o portal para a construção dos marcos de autorreconhecimento e autodiferenciação; sinais de pertencimento afetivo num mundo que dilui emoções e ilusões rapidamente e esfacela os meios para a memória.

\section{Considerações finais}

Conversar detidamente com mulheres que sofreram a violência direta ou velada da ditadura militar permitiu compreender de quantas lutas diferenciadas e ignoradas se fez a resistência contra o regime autoritário; quantas táticas fugiram do padrão, foram criadas e recriadas; de quantas experiências intersubjetivas se fez a história deste País e como a memória se torna necessária para entender a interligação do passado com o presente.

As entrevistas fizeram parte do diálogo coletivo, da necessidade de contar a história junto, a partir de tempos plurais, de papéis diferenciados e mundos complementares que convergiram para o território simbólico da negociação e da resistência, marca da identidade de uma grande comunidade de destino, como chamou Maurice Halbwachs (2006), contra o esfacelamento do tempo que condena as memórias de dor ao esquecimento.

Entender a astúcia e a coragem feminina promove a mudança na forma de se perceber a dinâmica das relações entre homens e mulheres, colocando nova proposição teórico-metodológica sobre a história, desprivilegiando o público como fazer histórico, dando importância às suas conexões com o mundo doméstico e particular. A vida política não foi nem é exclusivamente um feito masculino, segmentado da casa, da família e dos sentimentos mais íntimos.

Os testemunhos das mulheres atingidas pela repressão nos anos que marcaram o autoritarismo brasileiro ganham sentido de ensinamento e também de apelo ao ouvinte para uma "história a contrapelo", como queria Walter Benjamin. Cada pessoa que se dispõe a falar de suas dores neste momento torna pública uma história que também é nossa; seu relato torna quem viveu a experiência da dor responsável sobre o que diz, ao 
referência para que a sociedade possa continuar a caminhar de forma diferenciada, mais humanizada.

Se as pessoas no presente forem tocadas por suas histórias, elas poderão tocá-las de volta com sua compreensão, solidariedade, tornando-se disseminadoras de experiências femininas que se transformaram em conhecimento. Neste sentido, quem as ouve assumiria o papel de testemunha, não porque tenha visto com os próprios olhos ou tenha vivido diretamente os acontecimentos dolorosos, mas pela atitude solidária de não ir embora e de se tornar portador dessas histórias. Nas palavras de Gagnebin:

somente a transmissão simbólica, assumida apesar e por causa do sofrimento indizível, somente essa retomada reflexiva do passado pode nos ajudar a não repeti-lo infinitamente, mas a ousar esboçar uma outra história, a inventar o presente (GAGNEBIN, 2009, p. 57).

Os trabalhos com a história testemunhal de mulheres que viveram sob a ditadura mostram que, diante de suas narrativas, não assumimos apenas o papel de ouvintes como pesquisadores, pois a relação exige mais. Acabamos sendo também testemunhas de sua superação, de sua esperança e da própria grandiosidade da vida.

Neste momento em que o "dever da memória" se coloca para sociedades que recentemente saíram de ditaduras, como a do Brasil, os que não conheceram a privação da palavra, do direito de ser e de viver num outro tempo podem exercitar sua capacidade de reflexão e pensar sobre a responsabilidade de não esquecer as violações cometidas. É a ideia tão defendida hoje do "nunca mais", de que as "memórias subterrâneas" que emergem sejam norteadoras na construção de um país mais democrático e humano.

O trabalho com a história oral ganha, neste sentido, um papel social que ultrapassa a universidade, a Comissão da Verdade e as instituições jurídicas, publicizando experiências para reconhecê-las como parte de um passado e de um presente coletivos. É a procura pelos significados, pela ética, pela redenção de um passado que, segundo Walter Benjamin, permanece em aberto, revelando que a verdade histórica que parecia 
ter triunfado não era a única possível. A memória pode colaborar, neste sentido, jogandonos para dentro da vida.

\section{Referências bibliográficas}

BUTLER, Judith. Problemas de gênero: feminismo e subversão da identidade. Rio de Janeiro: Civilização Brasileira, 2003.

CARVALHO, Luiz Maklouf. Mulheres que foram à luta armada. São Paulo: Globo, 1998.

COLLING, Ana Maria. A Resistência da mulher à ditadura militar no Brasil. Rio de Janeiro: Record/Rosa dos Ventos, 1997.

COSTA, Albertina de Oliveira. Memórias de mulheres do exílio. Rio de Janeiro: Paz e Terra, 1980.

FERREIRA, Elizabeth F. Xavier. Mulheres, militância e memória. Rio de Janeiro: FGV, 1996

FOUCAULT, Michel. Microfísica do poder. Rio de Janeiro: Graal, 1997.

GAGNEBIN, Jeanne Marie. Lembrar, escrever, esquecer. São Paulo: Editora 34, 2006.

HALBWACHS, Maurice. A memória coletiva. São Paulo: Vértice, 2006.

JELIN, Elizabeth. Mulheres e os direitos humanos. Revista de Estudos Feministas. Rio de Janeiro: CIEC/ECO/UFRJ, v.2, n. 3, p. 117-149, 1994.

JOFFILY, Olívia Rangel. Esperança equilibrista: Resistência feminina à ditadura militar no Brasil. 2005. Tese (Doutorado) - Pontifícia Universidade de São Paulo -São Paulo.

LE GOFF, Jacques. História e memória. Campinas: Unicamp, 1997.

MEIHY, José Carlos Sebe Bom. História oral testemunhal, memória oral e memória escrita e outros assuntos: Entrevista. Revista História Agora, São Paulo, 2010.

PASSERINI, Luísa. A Memória entre Política e Emoção. São Paulo: Letra e Voz, 2011. 
PASSERINI, Luísa. Memoria y utopia: la primacia de la intersubjetividad. Valencia: Universitat de Valencia, 2006.

PERROT, Michelle. As mulheres ou os silêncios da história. Bauru: Edusc, 2006.

PERROT, Michelle. Escrever uma história das mulheres. Cadernos Pagu, Campinas: Unicamp, n.9, p.9-28, 1995.

POLLAK, Michael. Memória, esquecimento, silêncio. Estudos Históricos. Rio de Janeiro, v. 2, n. 3, p. 3-15, 1989.

RAGO, Margareth. A aventura de contar-se: feminismos, escrita de si e invenções da subjetividade. São Paulo: Unicamp, 2013.

RIBEIRO, Maria Cláudia Badan. Experiência de luta na emancipação feminina: mulheres da ALN. 2011. Tese (Doutorado) - Universidade de São Paulo, Faculdade de Filosofia, Letras e Ciências Humanas - São Paulo.

RIDENTI, Marcelo. As mulheres na política brasileira: os anos de chumbo. Tempo Social, USP, São Paulo, 2 (2), 2.sem. p. 113-128, 1990.

ROSA, Susel Oliveira. Mulheres, ditaduras e memórias: não imagine que precise ser triste para ser militante. São Paulo: Intermeios, 2013.

ROVAI, Marta G. de Oliveira. Osasco 1968: a greve no masculino e no feminino. Salvador: Editora Pontocom, 2013.

SALVATICI, Silvia. Memória e gênero: reflexões sobre história oral de mulheres. Revista de História Oral, v. 8, n.1, p.29-42, jan./jun. 2005.

SARLO, Beatriz. Paisagens imaginárias: intelectuais, arte e meios de comunicação, São Paulo: Edusp, 2005. 
O direito à memória: a história oral de mulheres que lutaram contra a ditadura militar (1964 - 84)

Recebido em: 30/08/2013 Aprovado em: 14/10/2013

\section{Universidade do Estado de Santa Catarina - UDESC \\ Programa de Pós-Graduação em História - PPGH \\ Revista Tempo e Argumento \\ Volume 05 - Número 10 - Ano 2013 \\ tempoeargumento@gmail.com}

